Tucker, Ericka. "Feminist Political Theory," in Michael Gibbons (ed.) The Encyclopedia of Political Thought. New York: Wiley Blackwell, 2011: 10331036

Feminist Political Theory

Ericka Tucker

Cal Poly Pomona University

Eltucker@csupomona.edu

7269

\title{
Feminist Political Theory
}

Born out of the struggles of the feminist movements of the 20th century, feminist political theory is characterized by its commitment to expanding the boundaries of the political. Feminism, as a political movement, works to fight inequality and the social, cultural, economic, and political subordination of women. The goal of feminist politics is to end the domination of women through critiquing and transforming institutions and theories that support women's subordination. Feminist political theory is a field within both feminist theory and within political theory that takes a feminist approach to traditional questions within political philosophy, contemporary and historical. In this entry, I will explore the nature of feminist political theory by asking two questions: what is feminist about feminist political theory, and what is specifically political about feminist political theory.

\section{What is 'feminist' about feminist political theory?}

What surprises many who are unfamiliar with feminist political theory is that it's not just about women or gender. There are no strict necessary and sufficient conditions for being 'feminist', due both to the nature of categories and to the myriad developments, orientations and approaches within feminism. Certainly, understanding and analyzing the political effects of gendered contexts is an important field of feminist political theory; however, feminist theory, and hence feminist political theory, is about more than gender. Feminist political theorists are found throughout the academy 
-- in departments of political science, history, women's studies, sociology, geography, anthropology, religion, and philosophy. Although there are disciplinary differences within these movements, feminist political theorists have, throughout the history of feminist political theory, discussed with one another and recognized one another as 'feminist political theorists'.

Feminist political theorists employ characteristic strategies, methods, values, and concerns. There is a normative and methodological core to feminist political theory, consisting of one of more of the following:

- Concern with power relations, whether these are gendered, physical, racial, class-based, or cultural, etc.

- Openness to question seemingly natural objects, such as the self, the family, the existing modes of political discussion and debate. Feminist political theorists illuminate and question the power relations embedded in these seemingly natural institutions.

- Critique of the history of political philosophy and its norms and theories.

- Critique of the history of feminist political theory and its norms and theories.

- Critique theoretical exclusions, with the goal of understanding the experience and values that are excluded by mainstream political theory and with an eye toward constructing theories that are inclusive.

- Rejection of essentialism, the notion that social categories are unchangeable with essences that map onto given characteristics and inequalities. Although some feminist political philosophers, often called 'difference feminists', have taken up the idea that there is a feminine essence, even these feminists argue that the patriarchal or sexist concept of 'woman' is not the 'essence' of women. On the other side of 
this debate are those that argue that all social identities are constructed. Others propose that we cannot know what 'women' are or whether there is an essence of women until we remove the barriers to women's empowerment.

- Focus on experience or critical understanding of individual experience; this is sometimes called 'situatedness'. Although this is a contested concept in feminist political theory, even those who critique the notion of first person experience recognize the value in testing one's views against the lived experiences of men and women.

A further norm of feminist theory and practice is the notion of reflexivity. Reflexivity is a methodological norm that requires that one's theory should be applicable to one's own experience. Sometimes this norm is seen as an ethical requirement of recognizing one's own political, social, economic and cultural location or position. Recognizing one's sitatuatedness and then reflecting on how one's theoretical commitments may be tied to this location begins a process of recognizing how one's 'positionality' affects one's abstract theory. From this work, which is both experiential and theoretical, but focused on oneself, the feminist theorist can appreciate how this theory might be taken differently by those differently positioned.

Perhaps the most characteristic element of feminist political theory is its commitment to enlarge the scope of the political. The famed slogan the feminist movement, "the personal is political," points precisely to where politics are to be unearthed - in the personal, in the private, in women's everyday experiences of subordination and inequality. Since Aristotle, the 'political' has been the realm of the giving and receiving of reasons. The political realm was one where the social institutions could be questioned and changed, and a place where the principles guiding human life met with the particularities of those lives. However, as Mansbridge and Okin write (Mansbridge and Okin, 2007: 335) Aristotle defined 
politics as the affairs of the polis, simultaneously defining the "household as other," as the realm of the non-political, and thus a realm that could not be questioned. This definition of the polis as what happens in public, as distinct from the private, sets the boundaries of political thought up until the 20th century. Political philosophy focused on the public, thereby excluding from the scope of their inquiry the realm of the private, the realm of women, the family, and the work and power relations therein. Feminist political theorists aim to bring the light of political analysis to the 'private'.

In the public, from which women were excluded, men set the terms of their public and private power. Women were forcibly and legally excluded from participating in public. They could not vote, matriculate into most institutions of higher education, or serve in military institutions. Women were excluded from political participation even as laws they had no hand in crafting or voting upon cemented their inequality in matters of voting, divorce, property ownership and labor. Political philosophers, to the extent that they addressed these issues, tended to present arguments for women's continued exclusion from the public and for the paternalistic care of their interests by heads of households. Susan Moller Okin's work showed that the world of the household was structured by hierarchy, domination and inequalities which were not justified and since beyond the realm of the 'public', were treated by political theorists as requiring no justification.

Feminist political theorists showed that when we look to the private realm, what we find is a highly unequal set of power relations and questionable assumptions about human motivation. Key theoretical and political outcomes of this project include: the political recognition of household work as labor; the legal recognition of marital rape and domestic violence as crimes; challenges to the notion that women are the natural and therefore justly exploited primary care-givers of children and the elderly; and challenges to the view that the head of household automatically can be taken to fairly 
represent the interests of his family. The idea of the head of household as a benevolent shepherd of the interests of his servants, women and children, is an idea that persists in economic theory. Feminist political theorists revealed that the private, rather than a realm structured by nature and benevolent paternalism was structured by unjustified political inequalities.

With this new insight into the power relations of the private and their effect on women's ability to participate in the public, feminist political theorists sought to show that the very distinction between private and public fostered the domination of women. Women's subordination in the private realm of the household, and the devaluing of household work as labor, made possible egalitarianism for men in the public. In her book The Sexual Contract, Carole Pateman argues that the sexual division of labor in the household and its hierarchical relations placing the husband as the representative of the family is best understood as a contract prior to the "social contract', which is among men who are understood as equal and independent. This 'sexual contract', marriage, excludes women from political participation, subordinating them to the will of their husband, who will represent their interests in the public. The world of liberal egalitarian rights guaranteed by a social contract was built, she argued, on a foundation of exploitation and domination.

\section{The 'Subject' of Political Theory}

Feminist political theorists argued that the subject of political theory, particularly the liberal and democratic political theory was actually coded male, and constructed in the image of a man. The liberal subject is a political agent: one who is both the subject of rights, one who bears in his or her person political and social rights, and the individual who is responsible for crafting and fighting for the realization and protection of those rights. The liberal subject or political agent able to act in the public realm was theorized as: independent, equal, rational and thus, autonomous and impartial. 
Although many have appealed to these values as universal, as true of all people, they were used and in some instances continue to be used to exclude women and other individuals.

Women, by definition, but also through a great deal of political theorizing, were seen as embodying the opposite of each of these descriptors. Women were often legally dependents of their husbands or fathers, making them unfit for liberal agency, never mind women's exclusion from guilds, professions, and nearly all avenues toward legally independent status. To be legally independent, at the time when Hobbes, Locke and Kant were fashioning the modern social contract and our conceptions of liberal rights was somewhat different than our current usage. The term 'independent' was reserved for those who were not wage-workers, servants, slaves and others who were legal dependents of others. This excluded more than women. The independence of the liberal subject of the social contract, Susan Moller Okin argues, is made possible by the exploitation of his 'dependents', those servants and women who do the work of caring for the physical and emotional needs of the public representative of the household. However, the work they engage in to make the head of household independent is that which ensures their status of 'dependents' and excludes them from political participation.

Women's natural subordination and inequality was taken for granted or affirmatively argued for by most liberal political philosophers of the western canon. There are some exceptions, including Hobbes, but to the extent that political philosophers recognized the existence of women, they were excluded from being 'equal' to the task of citizenship.

Kant argues that women's inability to control their emotions, and thus, their inability to be impartial or rational, requires their exclusion from political participation. Kant, of course, is not alone in the history of political philosophy in arguing that women are too emotional or partial to be considered rational. However, his conception of the social contract placed reason as a central 
requirement for political participation. His 20th century followers, Rawls and Habermas, took up this notion of 'reason'. Reason allows impartiality and autonomy; since women were dependent and connected with nature, emotion, and physical weakness, their ability to give laws to themselves and act impartially was seriously in question. Feminist political theorists have elucidated the way in which western political theory constitutes women's exclusion from political life through examining the way the 'political subject' or agent is defined by these political philosophers.

Feminist political theorists, although nearly unified in their critique of this notion of the liberal political subject and its historical use to exclude women, differ greatly their views of how to move forward. Liberal feminists have tended to argue that the values of liberalism embodied in this subject are important: autonomy, equality and justice are goals toward which feminists should aim. The history of women's exclusions from the political realm is the real problem, not the values themselves. Martha Nussbaum argues that the history of liberal theorists' exclusion of women has been one of a dearth of commitment to liberal values of autonomy and equality.

In opposition to liberal feminists' attempts to refashion the liberal values and liberal subject as something that feminists could use for emancipatory projects, socialist feminists, radical feminists and so-called difference feminists argued that liberal values were ineluctably based on the exclusion of the oppressed: women, workers, and minorities. Rather than take up the ideals of liberal theory, each of these groups proposed its own solution. Difference feminists argued that rather than deny the 'feminine' or devalue it, feminists ought to support and champion the feminine virtues, and to celebrate women's connectedness to children, family and community, women's closeness to nature, and their cognitive virtues of emotion and imagination rather than cold rationality. The problem, these theorists argued, was not the properties in themselves, but the devaluation of these virtues in contrast to those understood as masculine. Difference 
feminists sought to achieve a transvaluation of values, by arguing, as Naomi Scheman does, that the characteristics of the liberal subject make that subject technically 'paranoid', and by arguing as Carol Gilligan did that a moral scale which values objectivity and the ability to apply general moral principles over one which focuses on the particular details of a moral problem is backwards. Difference theorists argue that the central value of political philosophy, 'justice', which requires that equals be treated equally, and that each receives his or her due, is denied to women based on their 'difference' from men, based on their inequality. Given this androcentric focus on justice in political philosophy, many feminist political theorists have sought to create and define feminist political values, such as 'care'.

Radical feminists argued that both the 'feminine' virtues and the 'masculine' virtues were a product of male domination. As such, neither set of characteristics is particularly appealing. By taking up devalued 'feminine' characteristics, one willingly takes up a subordinated position in the family and in the political world; by taking up 'masculine' characteristics and despising the feminine, one supports the notion that these masculine traits are superior. Rather, many radical feminists take the view that we do not yet know what men and women can be, outside of patriarchal communities. The movement for separatism, the idea that women should live together in communities excluding men, was based on the idea that only in such communities could male domination be controlled, and women's identities developed without being deformed by patriarchal domination.

Feminist humanists argue that both the 'masculine' ideal of autonomy and separateness and the 'feminine' ideal of care and connection are oversimplified. A new ideal of the human subject and a new set of values ought to be part of a collective political project seeking emancipation for both women and men.

Poststructuralist feminists take up this problem and change its direction: they focus on what they call the process of 
'subjectivization', the methods, practices, institutions and norms which fashion human beings into 'subjects', e.g. men and women. Entirely opposed to an idea of women's essence, poststructuralists insist that in order to understand and critique these social categories, and indeed even biological categories, we need to investigate the power relations, which create these conceptual schemes. We must dig beneath the explicit justifications for these, biological difference, and be attentive to what they call 'micropolitics' and 'bio-power'.

Judith Butler used these techniques to overturn one of the most stable and famous conceptual distinctions in feminist theory, the difference between sex, which was supposed to be biological and gender, which was supposed to be cultural. Butler argues that the body and the biological are no less political and cultural creations than gender. The discourses surrounding biological sex are already gendered, and both play important roles in the process of creating and constructing political subjects. This process of subjectivization does not provide us with citizen subjects with full agency, as in the liberal model. Rather, poststructuralists understand the subjects as bound by practices and power relations that are both dominating and productive. Following Foucault, feminist poststructuralists argued that the theory of power as domination was false; they sought to understand how power relations at the most mundane levels created a complex web which yielded the bodies of women and men.

Understanding power as complex and positive makes the question of overcoming domination and emancipating much murkier. Poststructuralist theorists were critiqued for abandoning the feminist political project of emancipating women and of making power so diffuse as to be no longer something that could be 'fought'. If what characterizes feminist theory and the program of feminist politics is the goal of bringing to light the oppression of women, then, some argued, poststructuralist feminist theory marks the end of feminist political theory as a feminist project, while others simply excluded poststructuralist feminist theory as neither feminist nor political, but 
Tucker, Ericka. "Feminist Political Theory," in Michael Gibbons (ed.) The Encyclopedia of Political Thought. New York: Wiley Blackwell, 2011: 10331036

rather as theory for its own sake.

\section{Feminist Political Theory: A History of 'Productive' Struggle}

Although above I have set out major elements of feminist political theory, these concepts have been the outcome of decades of political arguments among feminist political philosophers and between feminist activists and feminist theorists. Some periodize these differences in terms of waves and generations; others theorize them in terms of the differences between groups, liberal feminists, difference feminists, socialist feminists and radical feminists. However, the differences in feminist theories rarely respect the boundaries of these generations and ideological groupings. Many productive debates have arisen and continue to arise from perceived violations of the norms of feminist theorizing practice. These norms include: the goal of inclusion, rejection of essentialism, reflexivity and mutuality, and contributing to the political project of women's emancipation.

From violations of these norms come central feminist positions, which, though not held by all feminist political theorists, are well known and recognizes as feminist political theories. Feminist political theory, since its beginning, has been thought of as the theoretical organ of the movement for women's emancipation, with its central interest being this political project. Queer feminists and feminists of color, excluded by white middle class feminists in the 1960s and 1970s, articulated now classic political critiques of the increasingly mainstream feminist movement. These critiques from the inside and outside of feminist practice created a rich and multilayered set of concepts, theories and critiques, which added an enormous amount to political philosophy. The real issues confronting the movement affected and set the challenge for feminist political theorists. At the same time, theoretical movements within the academy shaped the topics and discourses of feminist political theorists. 
Telling the history of feminist political theory and how its major figures from the 17th to 19th centuries yield the flourishing of feminist political theorists in the mid-20th is beyond the scope of this essay. I direct the reader to the excellent sources below for a good historical overview and for current projects that are attempting to reintegrate women philosophers and political theorists from the early modern and enlightenment into the canon of political theory.

For the purposes of this essay, I propose that what began as a set of debates about the question of gender and politics from politically affiliated groups of Marxist, Socialist, Radical, and Liberal feminists has development into what we now call 'feminist political theory'. This move towards creating an academic field, some argue, has worked to depoliticize the movements from which feminist political theory derived. Whether feminist political theory has a practical political valence is debatable. What is clear is that what has emerged as feminist political theory allows a variety of political stances and has created characteristic questions and research programs, which themselves continue to spawn new subfields within feminist political theory.

Early feminist theorists were concerned not just with questions of politics, as identified by political theories. They were also interested in politicizing unquestioned elements of everyday life that attention to gender, race and class made visible. Feminist political theorists sought to expand the boundaries of the political.

\section{What is 'Political' about Feminist Political Theory?}

We ask the second question, what is political about feminist political theory, because there is a sense in which all feminist theory focuses on expanding the boundary of the political. Thus, some feminist epistemologists argue for such theories as standpoint epistemology. Standpoint epistemology is the view that different social and economic locations produce different views of the world. Moreover, the more privileged one's economic and social position, 
the less likely one will have a true understanding of reality.

Standpoint epistemology, building on feminist theories of women's subordination, finds women to be the least privileged, and thus most likely to have a standpoint that is veridical. The interdisciplinary nature of feminist theory means that political questions of oppression are connected to epistemological questions of who can know the world. Political challenges to the view that women are the 'most oppressed', or metaphysical challenges to the idea that there is a real natural kind, "women", or sociological challenges to the view that the group "women" is more salient than groups like "Latina women" or "women of color", have real impact on the epistemological framework.

With the boundaries between politics, sociology, epistemology and metaphysics so often intersecting, what makes feminist political theory specifically 'political'? What sets feminist political theory apart as a separate field of feminist inquiry, given the nearly universal feminist interest in power and politics? In what follows, I will suggest that what makes feminist theory political is a constant engagement with political issues and a continuing dialogue among feminists.

\section{'A Feminist Lens': The Variety of Feminist Lens and the Struggles by which they were Ground}

Feminist political theory is fundamentally a set of theorists debating, disagreeing and critiquing. Thus, although I have set out the variety of characteristics of what counts as feminist political theory, what is most interesting and what keeps feminist political theory relevant are the differences between feminist political theorists. There is not just one feminist lens or political theory, but rather a variety of feminist lenses or theoretical and practical perspectives through which feminists critique one another and the political, economic, social and cultural phenomena that impede the emancipation of women. Below, I will briefly introduce the major schools of feminist political thought. Brevity necessarily diminishes the complexity of 
these schools and authors, but I hope that these quick overviews will lead readers to explore each of these areas more thoroughly.

A quick historical/methodological note: many of those writing on the history of feminist political theory organize this history in terms of the waves of women's movements. Following that schema, I have an overview of the first wave of women's political theory, the late $19^{\text {th }}$-early $20^{\text {th }}$ century movement for women's rights. I follow this with the major schools of second wave feminism: socialist feminists, liberal feminists, radical feminists and Black feminists. These groups developed some of the major theories of feminist politics, and their dialogues and disagreements with one another characterized feminist political theory until the 1980s. Difference feminists emerged in the 1980s. Debates among these feminists influenced the new schools of poststructuralist feminists in the 1990s. In the late $90 \mathrm{~s}-$ early $2000 \mathrm{~s}$, these groupings of feminist theorists changed in a variety of ways. The globalization movement and its insistence on the global but perhaps not universal character of women's oppression and political theory yielded a renewed anarcha-feminist movement and postcolonial feminism. Further, areas of inquiry such as feminist legal theory provided a new set of political problems that gained the attention of feminists from a variety of political affiliations and disciplines.

\section{Feminist Political Theory Pre-history}

Before there were movements and schools, there were texts of women writing in a new way about women's abilities and protesting women's exclusion and subordination.

Key primary texts include: Christiane de Pizan, City of Women, Mary Astell, A Serious Proposal to the Ladies, for the Advancement of Their True and Greatest Interest, Charlotte Perkins Gilman, Women and Economics, Mary Wollstonecraft, $A$ Vindication of the Rights of Woman, Olympe de Gouges, Declaration of the Rights of Woman and the Female Citizen, Virginia Woolf, A Room of One's Own, Simone 
de Beauvoir, The Second Sex.

Recovering feminist political theory pre-history has also involved feminists rereading the canon of political thought. I particularly direct readers to Nancy Tuana's excellent monograph series from Pennsylvania State University Press: 'Re-reading the Canon'. Each volume in the series focuses on a single author in the 'canon' of Western philosophy, covering figures from Plato to Rorty. Essays in each volume interpret different aspects of these figures from feminist perspectives.

\section{Women's Rights Theorists}

The women involved in the movement for women's rights began, for the most part, as part of the international movement to abolish slavery. They organized under many political banners and religious affiliations, and sought equal political rights with men, in particular the right to vote. They countered cultural norms of women as weak, irrational and unable to participate in politics. Arguing forcefully against the cult of domesticity, they argued that women did not have a special nature, suited to home and hearth, but were rather entitled to the civil and political rights of all. Members of the suffrage movement worked internationally and locally for women's political rights, rights to divorce, rights to inheritance, rights to matriculate into colleges and universities, etc. Although the $19^{\text {th }}$ century movement for women's rights in the United States and Europe received their activist training in the abolition movement, not all the $19^{\text {th }}$ century women's rights theorists continued to support the equal rights of all Americans after the civil war. As Angela Davis writes in Women, Race, and Class, several major women's suffrage supporters became hostile to the movement for Black liberation after Black men received the vote and they did not at the end of the civil war. Key figures include: Elizabeth Cady Stanton, Carrie Chapman Catt, Sojourner Truth, Anna Howard Shaw, Maria Stewart, Alice Paul, Frances E. W. Harper, Susan B. Anthony. 


\section{Radical Feminism}

Radical feminists argue that at the heart of women's oppression is male domination, which is pervasive. Male domination is built into the conceptual and social architecture of modern patriarchal societies. Men dominate women not just through violence and exclusion but also through language. Thus, Catherine MacKinnon's famous line, "Man fucks woman; subject verb object." (Mackinnon, 1991) Thus, radical feminists seek to identify and institutions based on domination and provide the tools for simultaneously critiquing and recreating relationships and cultural forms not based on domination. The strongest forms of radical feminism argue that there can be no reform, but only recreation of the notions of family, partnership, and childrearing, and that to do so in a way that preserves women's dignity requires the creation of women-only spaces. Key figures include: Shulasmith Firestone, Mary Daly, Andrea Dworkin, Katherine Mackinnon, Sarah Hoagland and Marilyn Frye.

\section{Socialist feminism}

Socialist feminists begin with a class analysis and argue that the fundamental force of masculine domination is economic. There are as many varieties of socialist feminism as there are socialist theories, but they range from the somewhat superficial analogy between the domination of the working class by capitalists to the domination and exploitation of women by men to the highly sophisticated examination of the workings of gender in economic policy. Socialist feminists have offered powerful theoretical arguments exposing women's economic, political, and emotional exploitation as part of a broader analysis of class and of the effects of capitalism. Socialist feminists and Marxist feminists joined together to critique liberal feminists reliance on the political aims of liberal politics, often arguing that one could be politically equal and yet economically and socially oppressed and thus unable to use one's political freedoms 
Tucker, Ericka. "Feminist Political Theory," in Michael Gibbons (ed.) The Encyclopedia of Political Thought. New York: Wiley Blackwell, 2011: 10331036

equally.

Key figures include: Charlotte Perkins Gilman, Angela Davis, and Nancy Fraser. Feminist critical theorists, such as Nancy Fraser, Seyla Benhabib and Iris Young, may also be considered socialist feminists, given the Marxist roots of critical theory. Each of these figures notes the important of class to an analysis of oppression and injustice.

\section{Liberal Feminism}

Liberal feminists argue that the central aims of liberal theory: freedom, equality, universal human rights and justice are the proper aims of feminist theory. Liberal feminists use figures and concepts from the liberal tradition to develop feminist institutions and political analyses. Martha Nussbaum, a liberal theorist, insists that most feminist theorists who claim to reject liberal values are in fact providing useful internal critiques of liberalism and show just how powerful the norms of liberalism can be for emancipatory feminist practice. Liberal feminists question the import of gender and suggest that emancipating women requires that they be treated and recognized as equal, rights bearing human agents. Key figures include: Mary Wollstonecraft, Martha Nussbaum and Susan Moller Okin.

\section{Black Feminism}

Although a diverse group, Black feminist thought (so-identified) began with the critique and rejection of the feminist movement's overwhelming concern with the lives and experiences of white middle class women. Black feminists argued that white feminist theorists were comprehensively excluding the experience of women of color and working women from their movement and from their political analyses. Black feminists and others argued that feminist theory needed to analyze race along with class and gender to understand the different ways in which women were oppressed and exploited. Legal theorist Kimberle Crenshaw coined the term 'intersectionality' to describe the different forces of power and oppression that intersect 
differently situated individuals and affect the ways that they are exploited, marginalized or oppressed, although this had long been the substance of Black feminist critiques of radical and socialist feminism. Key figures include: Ida B. Wells, Mary Church Terrell, Alice Walker, Audre Lorde, Patricia Hill Collins, Kimberle Crenshaw, Gloria Hull, Patricia Bell Scott, Angela Davis, Beverly Guy-Sheftall, Barbara Smith, and Melissa Harris Perry. Alice Walker helped popularize the term 'womanism' as a movement to critique and analyze politics and culture from the point of view of women of color. Womanist political philosophy emerged out of a critique of white radical feminists who insisted that the political aim of women's emancipation could not be achieved with men. This effectively required Black women to choose between gender and racial solidarity, which womanists and Black feminists resisted. As a positive political philosophy, based in African American women's experience, womanist theory tells a different history of women's struggles for emancipation. More recently, black feminist thought has produced the offshoot 'Crunk feminist political theory', which provides gender, race and class analysis from the perspective of the hip-hop generation. Crunk feminists use the myriad tools of feminist critique to bear on popular culture, political, social and religious institutions, and political theory.

\section{Difference feminism}

'Difference feminists' are a diverse group, joined by their shared theoretical commitment to acknowledging the important differences of women, and arguing that women's emancipation can only be realized through recognizing and valuing these differences. This group tends to reject the notion that gender has no import or no biological, psychological basis. They each argue in a variety of ways that women and men are different, and that this difference offers unique ethical, social and cultural roles for women that should be valued, rather than denigrated. Feminist movements that are 
characterized by some view of the importance of 'difference' are cultural feminists, psychoanalytic feminists, such as Luce Irigaray, Carol Gilligan and Nancy Chodorow and care feminists such as Nel Noddings, Sara Ruddick, and Virginia Held.

\section{Poststructuralist/Postmodern Feminism}

Poststructuralist feminist theorists emerged in the 1990s, after the battles between socialist, liberal, radical and Black feminists. Influenced by French post-structural theorists, including Foucault, and Derrida, feminist poststructuralists were critical of notions of agency, freedom, consciousness, and unity that form the basis of most feminist projects. Poststructuralist, or postmodern feminists, rejected the dualisms of the previous 20 years of feminist theory: man/woman, reason/emotion, difference/equality. They challenged the very notion of stable categories of sex, gender, race or sexuality. Queer theory, in part, began with the radical questioning of the idea of sex and gender introduced by Judith Butler. Her work, Gender Trouble is considered a classic work both of poststructuralist feminist theory and queer theory. Key figures include: Donna Haraway, Linda Zerilli, Judith Butler, Wendy Brown, Luce Irigaray, Eve Kosofsky Sedgwick, and Gayatri Spivak.

\section{Postcolonial Feminism}

Postcolonial feminist theory emerged in the 1990s, in the postidentity politics era, and in the wake of the phenomena of increased global interaction referred to as 'globalization'. The aim of postcolonial feminist theory, argues Chandra Talpade Mohanty in Under Western Eyes, is to 'decolonize' feminist practice, part of which requires working for feminist solidarity versus 'global feminism'. Global feminism, the global cooperation of women to increase women's standards of living and to achieve equal human rights for women originated in the 19th century, with women cooperating in the international movement to abolish slavery. In the 
20th century the movements to empower women globally have multiplied. However, their focus tended to be on promoting western values and helping or saving non-western women. Mohanty argues that the paternalistic attitude of western feminists undermined the power and collective insight of women in the global South and ignored the ways in which Western feminism recapitulated western patriarchy. Uma Narayan in her work Dislocating Cultures compares western feminists paradoxical obsession with non-western practices that disempower women, including: 'veil', 'suttee' and 'FGM' while ignoring the widespread western practices of elective plastic surgery to mold female bodies into 'ideal' but unrealistic and often unhealthy forms.

Postcolonial feminist political theorists challenged westerndominated institutions, like the UN, the IMF, the WTO and others, as well as neoliberal western strategies for poverty reduction and development, often arguing that the western model of development is unsustainable and destructive, and not worth replicating. However, developing after the 1980s struggles with identity politics and the question of organizing as women while questioning the very nature of the category and the differences between women, postcolonial feminist theory can also be understood as a moment of synthesis.

Politically, in an age of globalization, where the voices and power of those already marginalized was becoming fainter, postcolonial feminist theorists argued that feminists must move beyond these theoretically impasses and find ways to work together. Mohanty proposes a vision of feminism that speaks to those in rich and poor countries and those engaged in feminist activism and theorizing. She writes, "Feminist practice as I understand it operates at a number of levels: at the level of daily life through the everyday acts that constitute our identities and relational communities; at the level of collective action in groups, networks, and movements constituted around feminist visions of social transformation; and at the levels of theory, pedagogy and textual creativity in the scholarly 
and writing practices of feminists engaged in the production of knowledge." (Mohanty, 2003: 5) Following Mohanty's notion of an engaged feminist theory and practice, poststructuralist feminist Gayatri Spivak argues for 'strategic essentialism'. While recognizing the many differences among women, feminists can work together as 'women' when it is strategically useful to do so. Common interests among groups can achieve political gains without being 'identical'. Both of these views contribute to the notion of global feminist cooperation as a kind of 'solidarity' in shared but diverse struggles among women from poor and rich countries.

\section{Feminist Legal Theory}

As feminist legal theorists focus on the law, they are supplied with a constant and fresh set of feminist questions that are both theoretically interesting, and important to the feminist political project. Feminist legal theory has also been the site of enormous success in the development of practical instruments to expose and vitiate women's oppression and subordination in the law. Feminist legal theorists in the 1980s and 1990s showed the practical import of the theoretical debates between liberal and difference feminism. Laws that protected women as equals to men would often practically harm them by not recognizing that practically, women's lives were different than men's lives. These theoretical battles have practical import, which is just as complex as the theoretical issues involved. Feminist legal theorists have achieved remarkable success in fighting laws that discriminate against women and in creating laws that recognize the ways in which women, because of their sex and gender, can be harmed. Feminist legal theorists have successfully created legislation that recognizes that rape need not be the result of physical overpowering to be considered rape, laws that recognize and punish marital rape and domestic violence, laws that allow parental leave for both parents, and laws that recognize the harm of sexual harassment in the workplace. Internationally, feminist legal scholars have successfully 
argued that rape should be understood as a war crime, as its aims are often genocidal. Feminist legal scholars also work to create international conventions on topics that affect women globally, including war, equal treatment under the law, conventions barring discrimination against women (CEDAW), etc. Key figures include: Katherine MacKinnon, Robin West, Kimberle Crenshaw, and Martha Fineman.

\section{Anarcha Feminism}

Following in the anarchist tradition, anarcha-feminists question the very foundation of political power and suggest that we should reconstruct political society from its bases. As such, anarchafeminism has a strong basis in 17th century state theory and in the variety of Marxist theory that engages with the withering of the state, and, of course, the long literature of anarchist political theory. With the development of the Occupy movement, anarcha-feminism and the strategies of the 1970s feminist movement, namely the strategy of consensus are back in the public eye and are gaining mainstream recognition. Key figures include: Emma Goldman, Red Rosia and Black Maria of the Black Rose Anarcho-Feminists, the Revolutionary Anarcha-feminist group (RAG) and Vandana Shiva.

\section{Conclusion}

The diversity within feminist activism and political theory goes beyond even the 'lenses' or perspectives set out above. As an on-going dialogue, feminist political theory continues to develop from within and without. From within, the various strains of political theory continue to emerge with new varieties of feminist political thought. Within the academy, feminist theorists bring feminist political analysis to anthropology, sociology, literary studies, economics, and legal theory (among others). Feminist political theorists using one or more of the 'lenses' identified above, bring the methods of feminist political theory to bear on the specific problems 
of their discipline, while examining the foundations of these disciplines and questioning long held assumptions about gender, sexuality, and power relations. From without, challenges to women's emancipation are myriad, providing challenges for feminist political theorists to understand both traditionalist rejection of women's empowerment and backlash. As political forces in the 2010s bring religious fundamentalism, nationalism, and right wing extremism to the forefront of global politics, feminist political theorists find themselves fighting for equality, reproductive freedom and for women's economic and political rights.

When we seek to find necessary and sufficient conditions that would distinguish feminist political theory from other developments in feminist theory, we find our task to be difficult - indeed, feminist political theorists were among the first to critique the notion of categories as those things that we could define with such precision. Feminist political theory is a living discipline, interacting with other feminist theorists and theorists of politics in myriad ways.

The borders between feminist political theory and feminist theory as such are permeable, but permeable for good reasons. Feminist political theorists continue to extend their questions beyond the boundaries of mainstream political theory, which often yields interacting with feminist theorists working on issues of culture, science, or education, for just a few examples. Further, feminist theorists who do not work in feminist political theory often seek to challenge or support a thesis of feminist political theory as part of their work. Feminist theory and feminist political theory, thus, are productively intertwined. However, with the institutional support for women's studies and interdisciplinary institutes within universities, feminist political theorists are able to move beyond the current debates in their home discipline of political theory, and create a specifically feminist political theory. This permeability between feminist theories and the very existence of feminist political theory depends on institutional structures, which can shift. 
Normatively, feminist political theorists approach questions of political theory, including freedom, sovereignty, equality, with a feminist lens, focusing on questions of gender, inequality, exclusions and hierarchies. Feminist political theorists, drawing on a background of political theory, and drawing from the work and dialogues between feminist theorists and activists, seek to expand the boundary of what is considered political, and help create a space for the critique of previously unquestioned norms, customs and values.

In the preceding I have attempted an introduction to the major issues, norms, and methods of feminist political theory, showing what is 'feminist' and 'political' about feminist political theory. For further information on this rich and complex field of both political theory and feminist thought, please consult the section 'Further Reading'.

Cross References

Abolitionism

Feminist Theory and Liberal Political Theory

Feminism

Gender and Identity Politics

Gender and Sex

Intersectionality

Marxist feminism

Misogyny

Motherhood

Patriarchy

Postcolonial Feminism

Public/Private Distinction

Sex-Gender Relationship

Socialist Feminism

Women in Western Political Thought

Women's Rights

Women's Suffrage 
Figures:

Iris Marion Young

Judith Butler

Susan Okin

Martha Nussbaum

Carol Pateman

Mary Wollstonecraft

Nancy Fraser

Luce Irigaray

Shulasmith Firestone

Christine de Pizan

References and Suggested Readings:

Antony, Louise M. and Charlotte Witt (2002) A Mind of One's Own. Boulder, CO: Westview Press.

Benhabib, Seyla, and Drucilla Cornell (1987) Feminism as Critique: on the politics of gender. Minneapolis: University of Minnesota Press.

Brown, Wendy (1995) States of Injury, Princeton, NJ: Princeton University Press.

Butler, Judith (1999) Gender Trouble: Feminism and the Subversion of Identity. New York: Routledge.

Butler, Judith and Joan W. Scott (1992) Feminists Theorize the Political. New York: Routledge.

Collins, Patricia Hill (2000) Black Feminist Thought. New York: 
Tucker, Ericka. "Feminist Political Theory," in Michael Gibbons (ed.) The Encyclopedia of Political Thought. New York: Wiley Blackwell, 2011: 10331036

Routledge.

Davis, Angela (1983) Women, Race and Class. New York: Vintage.

Fraser, Nancy (1997) Justice Interruptus. New York: Routledge.

Gibson-Graham, J.K. (1996) The End of Capitalism (As We Knew It): A Feminist Critique of Political Economy. Oxford UK and Cambridge USA: Blackwell Publishers.

Harcourt, Wendy (ed) (1994) Feminist Perspectives on Sustainable Development. London: Zed Books.

Hartsock, Nancy (1985) Money, Sex, Power. Boston: Northeastern University Press.

Hirschmann, Nancy J. (1992) Rethinking Obligation: a feminist method for political theory. Ithaca: Cornell University Press.

Hirschmann, Nancy J. (2003) The Subject of Liberty: Toward a Feminist Theory of Freedom. Princeton: Princeton University Press.

hooks, bell. (1981) Ain't I a woman: Black women and feminism. Boston: South End Press.

Jaggar, Alison M. (1983) Feminist Politics and Human Nature. Totowa, N.J.: Rowman \& Allanheld.

Jaggar, Alison and Iris Young (2000) A Companion to Feminist Philosophy. Malden, MA: Blackwell.

James, Stanlie M. and Abena P. A. Busia (1993) Theorizing Black Feminisms: The Visionary Pragmatism of Black Women. 
Tucker, Ericka. "Feminist Political Theory," in Michael Gibbons (ed.) The Encyclopedia of Political Thought. New York: Wiley Blackwell, 2011: 10331036

Kerr, J., E. Sprenger, and A. Symington (Eds.) (2004) The Future of Women's Rights: global visions and strategies. London; New York: ZED Books.

Lewis, Reina and Sara Mills (2003) Feminist Postcolonial Theory. New York: Routledge.

Lloyd, Genevieve (2002) Feminism and the History of Philosophy. New York: Oxford University Press.

MacKinnon, Catharine A. (1989) Toward a Feminist Theory of the State. Cambridge, Mass.: Harvard University Press.

Mohanty, Chandra Talpade (2003) Feminism without Borders: decolonizing theory, practicing solidarity. Durham: Duke University Press.

Moraga, Cherrie and Gloria Anzaldua (1981) This Bridge Called My Back. Persephone Press.

Narayan, Uma (1997) Dislocating Cultures. New York: Routledge.

Nussbaum, Martha C. (2000) Women and Human Development. Cambridge: Cambridge University Press

- (1999) Sex and Social Justice. Oxford: Oxford University Press.

Okin, Susan Moller (1979) Women in Western political thought. Princeton, N.J.: Princeton University Press.

- (1989) Justice, gender, and the family. New York: Basic Books.

Pateman, Carol (1988) The Sexual Contract. Stanford: Stanford University Press. 
Roth, Benita (2003) Separate Roads to Feminism: Black, Chicana, and White Feminist Movements in America's Second Wave. Cambridge: Cambridge University Press.

Shandley, Mary Lyndon and Carole Pateman (Eds.) (1991) Feminist Interpretations and Political Theory. State College, PA: Penn State University Press.

Shiva, Vandana (2010) Staying Alive. Brooklyn, NY: South End Press.

Young, Iris M. (2000) Inclusion and Democracy. Oxford ; New York : Oxford University Press.

- (1990) Justice and the Politics of Difference. Princeton: Princeton University Press.

- (1990) "Throwing like a Girl" and other essays. Bloomington, IN: Indiana University Press.

Zerilli, Linda. (2005) Feminism and the Abyss of Freedom. Chicago: University of Chicago Press. 